\title{
Physical Characteristics of Near-Shore Ice Ridges
}

\author{
M. LEONARD BRYAN ${ }^{1}$ and MELVIN G. MARCUS ${ }^{2}$
}

\begin{abstract}
Investigations of the morphology and composition of near-shore ice ridges were conducted on the southern shore of Lake Superior near Grand Marais, Michigan, and at other Great Lakes locations during 1970 and 1971. Data are given for ice densities, sediment load, temperature and internal arrangements of ice forms. A cross-sectional map of the gross structure of one ice ridge is also presented. The basic internal appearance of the ridges is similar to that of conglomerate rock, and little stratification occurs. These ridges are seldom discussed in the literature but commonly appear along the shorelines of the Great Lakes. It is suggested that they are developed primarily as a product of wind and spray processes and are not to be confused with pressure ridge and ice thrust features.
\end{abstract}

RÉSUMÉ. Caractéristiques physiques de crêtes glacielles riveraines. En 1970 et 1971 , les auteurs ont étudié la morphologie et la composition des crêtes de glace riveraines le long de la rive Sud du lac Supérieur, près de Grand Marais, Michigan, et sur les autres Grands Lacs. Ils présentent ici les données recueillies sur la densité de la glace, la charge en sédiments, la température et la disposition interne de ces formes glacielles, de même qu'une carte en profil de la macro-structure d'une crête. L'apparence interne des crêtes est semblable à celle des conglomérats rocheux, avec très peu de stratification. Ce type de crête a été peu étudié dans la littérature mais est commun le long des rives des Grands Lacs. Les auteurs supposent que ces crêtes se forment principalement sous l'action du vent et des embruns et qu'il ne faut pas les confondre avec des crêtes de pression ou des phénomènes de poussée glacielle.

РЕЗЮМЕ. Физические характеристики прибрежных ледяных глыб. В течение 1970 и 1971 годов на южном берегу озера Верхнего в районе Гранд Марэ, Мичиган, и на других Великих озерах проводились исследования морфологии и строения прибрежных ледяных глыб. Представлены результаты исследований плотности льда, осадочных нагрузок, температуры, внутренней структуры ледяных образований и, также, схема поперечного сечения полного строения одной из ледяных глыб. Внутренняя структура ледяных глыб напоминает структуру конгомерата; слоистость почти полностью отсутствует. Не смотря на то, что появление этих ледяных глыб вдоль побережья Великих озер является обычным явлением, обсуждается это в литературе редко. Высказывается предположение, что развитие этих ледяных образований, в основном, вызвано деятельностью ветра и брызг.

\section{INTRODUCTION}

A common characteristic of the Great Lakes in the winter is the variety of onshore and offshore ice features which occur along shorelines. Many of these features take the form of ridges and play a significant role, both as passive and as active agents, in the development of coastal morphology. It is generally assumed that these ridges are the result of ice thrusting and if so that they should reveal this origin in their internal structure. This is not evident for onshore and near-shore

1Institute of Science and Technology, The University of Michigan, Ann Arbor, Michigan, U.S.A.

2Department of Geography, The University of Michigan, Ann Arbor, Michigan, U.S.A. 


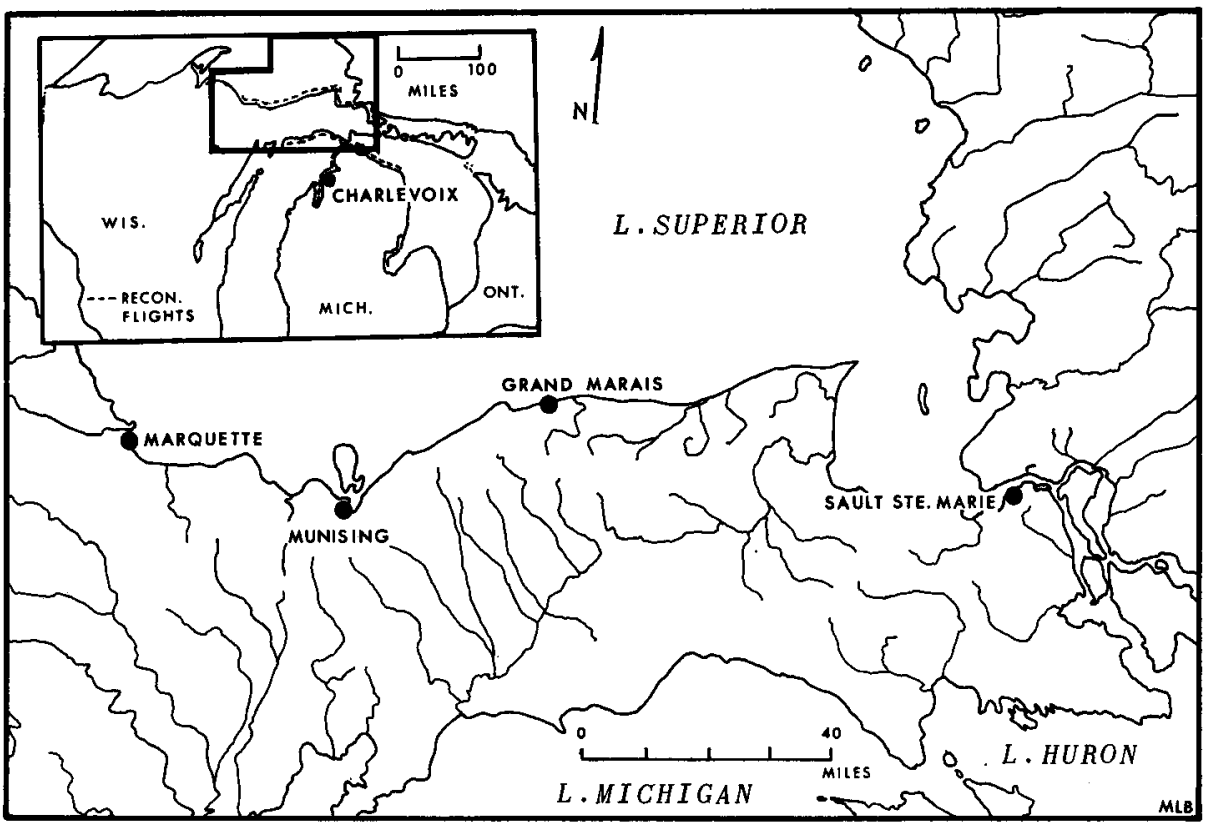

FIG. 1. Great Lakes Region. The Grand Marais study area is within the frame. Dashed lines follow air reconnaissance surveys of the shoreline.

ridges in the Great Lakes, where these features are the result of wave action, spray, and other processes related to the interaction of weather and water. This paper describes the structure, morphology, composition and distribution of such iceridged features and discusses hypotheses for their formation. Related field work was conducted along the shores of Lake Superior, Lake Huron, and Lake Michigan during the winters of 1970 and 1971, focusing particularly on ice ridges near Grand Marais, Michigan (Fig. 1).

\section{BACKGROUND AND TERMINOLOGY}

The effects of lake ice on shore morphology have been documented for over 150 years. In an early work, "Petros" (1822) dramatically described the shoreline movement of stones as ". . . rocks overcoming every obstacle in the sublime effort of escaping the domain of Neptune," and accredited them to ". . . some cause unknown ...". In 1825 two explanations for such shoreline modifications were presented. Adams (1825) suggested that the expansion of ice moved stones onto the shore. Wood (1825) remarked that the movement of rocks was due to ice rafting and wind action. In 1901 Buckley proposed a hypothesis for the formation of ramparts based on his field work in Wisconsin. Prerequisite to his scheme was the complete freezing of the lake surface. Then as the air temperature continued to lower, the ice would cool, contract and fracture. The cracks would fill with water infiltrating from below, with subsequent freezing and expansion. The pressure resulting from this expansion was thought to be released by either a thrusting of the ice sheet upon the shores (as postulated earlier by Adams), or by an arching 
of the ice resulting in both vertical and horizontal displacement, as suggested by Gilbert (1885, p. 109). Montagne (1963), working on a small arm of Yellowstone Lake, argued for Buckley's hypothesis of rampart formation.

Others have suggested that shoreline modification may be produced by the thrusting of floating blocks of ice upon the shore by wind and currents (Wood 1825; Tyrrell 1909; Ward 1959) and that these processes may be related to periods of ice formation and break-up (Hellaakoski 1932; Wagner 1970). A more complete discussion and bibliography concerning ice-shove is presented by Jones (1970).

Lake size, as one of the prime factors affecting the development of ramparts, has also been considered (Hobbs 1911; Scott 1927; Zumberge 1952). Generally, expansion ramparts are not to be expected on small lakes having a diameter in excess of 1.5 to $3.0 \mathrm{~km}$. For larger lakes, it is commonly believed that ridges formed along the shoreline are either wind-driven thrust features or pressure ridges characterized by numerous voids between the overturned and upturned blocks of ice (Fig. 2), and are morphologically similar to the pressure ridges discussed in polar literature (e.g. Gilder 1966, pp. 158-159). There are, however, several aspects of the interaction between lake ice and shoreline which are generally absent in the literature. Although there is much information regarding modification of shorelines by ice, there has been little research concerning the protection of the shoreline by the same ice. Also, there is little written concerning the development of shore ice features by processes other than the thrusting or faulting of existing ice floes, packs, and sheets.

Ice terminology, whether morphologically or genetically classified, is in a continuing state of flux. Many investigators have introduced definitions and descriptions, only to have these terms altered or ignored by subsequent authors. In addition, there is often a change of situation from sea ice to lake ice. Both Armstrong et al. (1966) and USNHO (1952) present several definitions of the term ice foot. With special reference to the Great Lakes, Marshall (1966, p. 31) states: "An icefoot can be composed of any combination of frozen spray or lake water,

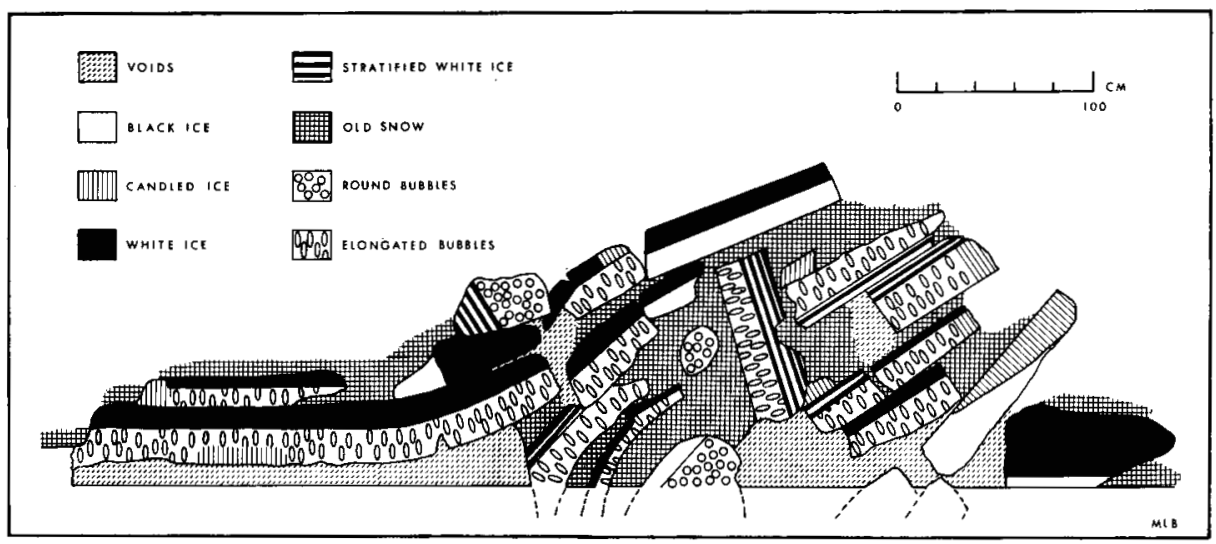

FIG. 2. Cross section of pressure ridge located $1.5 \mathrm{~km}$. from shore near Grand Marais, Michigan. 
snow accumulations, brash, stranded ice floes, and sand which is either thrown up on the icefoot by wave action or is blown out from the exposed beaches." Marshall's definition is preferred since it incorporates the process of accumulation of materials (both snow and sediment) from either side of the water/shore interface. It also emphasizes the importance of open water adjacent to the ridge as a source of frozen and liquid spray. This definition is also supported by recent observations by Marsh et al. (1972) and Garwood (1971).

Finally, two important requisites of icefoot development should be noted. Zumberge and Wilson (1953, p. 202) define these as: 1) sub-freezing atmospheric temperatures, and 2) open water bodies that, because of their size, remain ice free well into the season of sub-freezing air temperatures.

\section{RIDGE CHARACTERISTICS}

Near-shore ice ridges are ubiquitous throughout the Great Lakes wherever coastlines are exposed to prevailing wind and wave action, and temperature conditions are amenable to ridge development (Fahnestock et al. 1972; O'Hara and Ayers 1972). Generally two or three parallel ridges appear, the first developing at the shoreline. The remaining ridges are located up to 200 to $300 \mathrm{~m}$. from the shoreline. This pattern is reiterative along the reconnoitered shorelines of Lakes Michigan, Huron and Superior (Fig. 1). Detailed ridge investigations were conducted at Grand Marais, Michigan, during the early months of 1970 and 1971. The locality, on the southern shore of Lake Superior and approximately $110 \mathrm{~km}$. west of Sault Ste. Marie, Michigan, is exposed to winds from the northwest through northeast quadrants. The fetch ranges from $270 \mathrm{~km}$. for northwest winds to approximately $130 \mathrm{~km}$. for northerly winds. The beach at the study site is composed of sands and gravels. Several kilometres to the west are the Grand Sable Dunes, adjacent to the beach and characterized by bluffs of unconsolidated sands and clays up to $100 \mathrm{~m}$. high. The dunes are considered to be the source of some of the sand supply which is transported to the study area by eastward setting longshore drift.

\section{The Grand Marais Ridges}

Two icefoot ridges developed at the Grand Marais site during the winter of 1969-1970, although 3 ridges occasionally appeared in adjacent areas. The ridges have a cuesta-like form and attain heights of 1 to $3 \mathrm{~m}$. above water level. Strike is oriented parallel to the shoreline. Dip slopes occur on the landward side and are relatively shallow (less than 15 to $20^{\circ}$ ), while lakeward facing scarp slopes approach the vertical. In plan view the scarps present a scalloped effect (Fig. 3). Along the ridge line appreciable micro-relief occurs manifested by intermittent hummocks and cones.

In the winter of 1969-1970 ridge features did not develop at Grand Marais until January. During a reconnaissance on 3 January, only an intermittent cover of frazil and pancake ice was present. By 20 January when field work was reinitiated, two large ridges had been constructed. Approximately $125 \mathrm{~m}$. intervened between the shoreline and the outer ridge. A hummocky surface composed of ball 


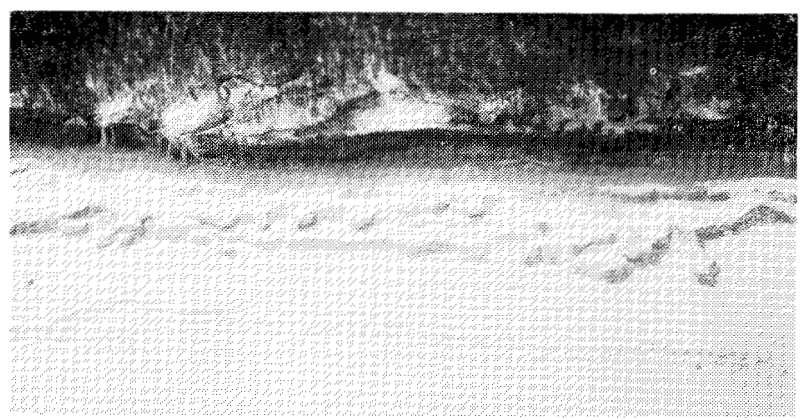

FIG. 3. Near-shore ice ridges west of Grand Marais, Michigan, 29 March 1970. Photograph: W. M. Marsh.

ice suspended in a matrix of solid lake ice characterized the lagoonal area. Lakeward of the outer ridge, pack ice formed a band extending 1 to $2 \mathrm{~km}$. in width. This band migrated throughout the winter season, sometimes making direct contact with the ridge scarp and at other times moving lakeward to leave open water between itself and the ridge. The composition of the ice pack was variable throughout the winter season, containing frazil, pancake, ball ice, black ice and slush. Both ice ridges remained intact until mid-April 1970, after which they melted and disintegrated over a period of several weeks.

\section{Structure and Composition}

On Thursday and Friday (21 and 22 January 1970) the interior of the outer ridge was exposed in a $3 \mathrm{~m}$. deep trench cut normal to the shoreline (Fig. 4). A 20 $\mathrm{cm}$. square grid was drawn on the exposed cross-section face, providing a base for

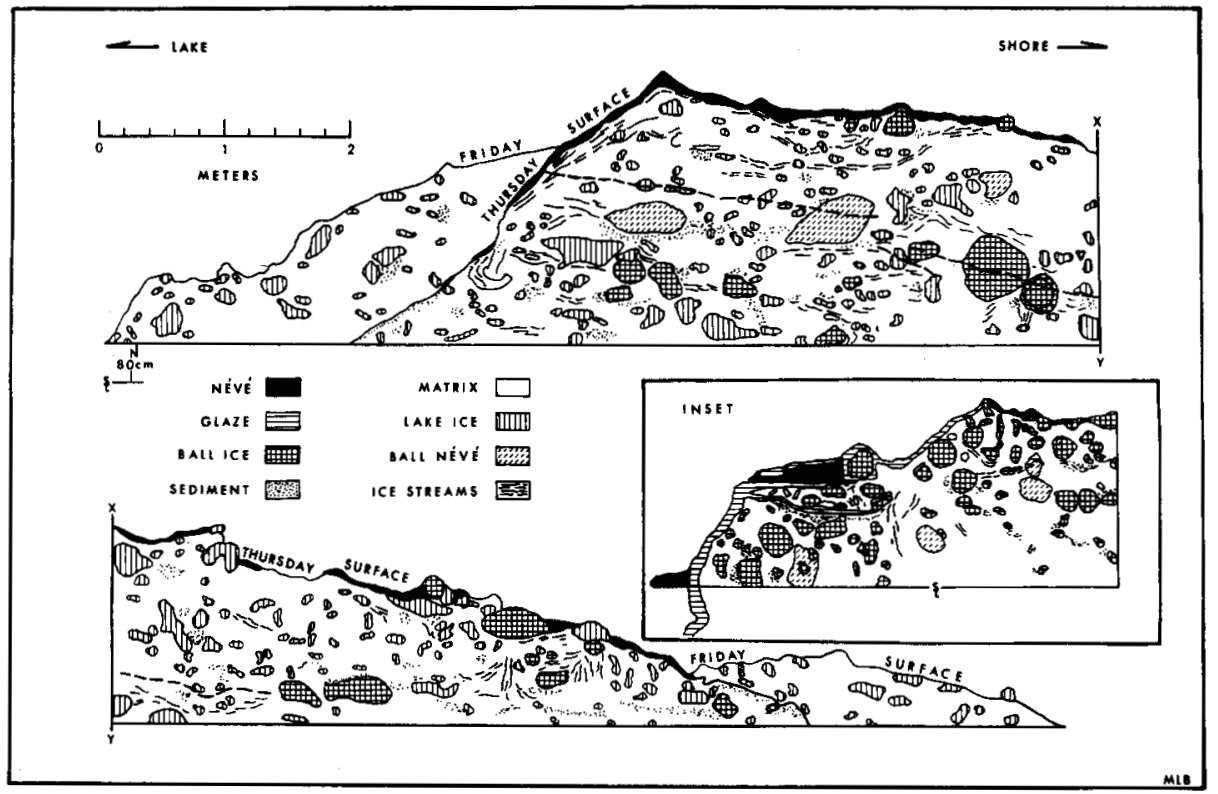

FIG. 4. Transverse cross-section of second Grand Marais ridge, 21-22 January 1970. The bottom of the cross-section is $80 \mathrm{~cm}$. above water level. Later lakeward development $(22$ February 1970) is shown in the inset. 
TABLE 1. Densities of component materials in ice-foot ridge, Grand Marais, Michigan

\begin{tabular}{|c|c|c|c|c|}
\hline Material & $\begin{array}{l}\text { No. in } \\
\text { sample }\end{array}$ & $\begin{array}{c}\text { Mean density } \\
\left.\text { (Mg.m. }{ }^{3}\right)\end{array}$ & $\begin{array}{l}\text { Range of } \\
\text { densities }\end{array}$ & Other characteristics \\
\hline Matrix & 16 & 0.57 & $0.49-0.63$ & $\begin{array}{l}\text { Spherical droplets } \\
(0.5-1.0 \mathrm{~mm} \text {.) when } \\
\text { fresh; some liquid } \\
\text { veneer. Hoar type } \\
\text { when old; spray origin? }\end{array}$ \\
\hline Glaze & 2 & 0.78 & $0.77-0.80$ & Solid; splash origin? \\
\hline Ball Ice & 16 & 0.69 & $0.61-0.81$ & $\begin{array}{l}\text { Slushy appearance; } \\
\text { concentric layers. }\end{array}$ \\
\hline Ball Névé & 17 & 0.62 & $0.56-0.67$ & $\begin{array}{l}\text { Believed metamorphosed } \\
\text { from former surface } \\
\text { snow in hollows. Long } \\
\text { axis tends to horizontal. }\end{array}$ \\
\hline Black Ice & 5 & 0.80 & $0.78-0.83$ & Lake ice origin. \\
\hline Frozen Slush & 4 & 0.83 & $0.74-0.90$ & Internal melt and refreezing \\
\hline Black Ice & 3 & 0.80 & $0.78-0.82$ & $\begin{array}{l}\text { Taken from lake beyond } \\
\text { ridges (for comparison). }\end{array}$ \\
\hline
\end{tabular}

mapping structure and included materials. Six types of frozen material were identified and sampled for density and other physical properties (Table 1). The appearance of the ridge interior was similar to that of a boulder conglomerate.

A variety of materials - ball ice, ball névé and lake ice - were imbedded in a matrix of fine-grained ice crystals. The matrix had a relatively lower density than the imbedded materials (Table 1). Individual matrix particles ranged from 0.5 to $1.0 \mathrm{~mm}$. at maximum dimension and varied from spherical droplets shortly after formation to depth hoar crystals later in the season. The maximum dimension of imbedded materials ranged from a few centimetres for the smallest blocks of lake ice to larger than 1 metre for ball ice and ball névé.

\section{Ball Ice}

The ball ice at Grand Marais was often concentrically layered, presented a wide range of densities, and frequently included silt- and sand-sized sediments. The processes operative in the formation of ball ice have been speculated upon by several authors. Loewe (1949), based on observations in antarctic and subarctic waters, suggests that their formation is the result of the coalescence of frazil or pancake ice worn down by wave action and collision. The ball ice he describes is distinguished from the fresh water type in Lake Superior by its origin in deep salt water, "soft and spongy" texture, lack of internal structure, and smaller diameters.

Loewe favours a second explanation: that snow flakes fall on the water surface at near freezing temperatures and continue to float. He observed that, "The movement of the water brought them into contact with each other so that they stuck together, the agglomerate becoming rounded by water movements and the impact of other solid particles." (Loewe 1949, p. 340). This process was observed to occur in the Great Lakes by Marshall (1966, p. 22) during a period of localized snow 
squalls which left snow and slush patches on the water surface. He states, "This ball ice was composed primarily of slush which was shaped by the turbulent water conditions offshore from the cliffed icefoot into lumps and balls up to 1 meter in diameter."

Near the shore, additional growth may occur as wave action moves the ball-ice nuclei in and out of the shallow zones where sediments are acquired by contact with the bottom or from suspended materials. Since the water is at critical ice growth temperature, the ball ice may layer rapidly with each successive exposure to sediments. An excellent illustration of this feature from Lake Huron at Rogers City, Michigan, appears in Marshall (1966, Fig. 20, p. 25). A rough analogy, in terms of the concentric arrangements of the layers, may be made between ball ice and hailstones.

\section{Ball Névé and Black Ice}

Ball névé, although morphologically similar to ball ice, has a significantly different internal structure and composition. It is homogeneous, has a crystal structure similar to that found in firn or névé, and lacks sediment content. Ball névé is believed to form from fallen or drifted snow that collects in hollows on the lee (i.e. shoreward) slopes of the ridges. Thus protected from intense wave action, but exposed to solar heating, it metamorphoses to névé. Subsequent accretion of ice buries the névé ball within the ridge. Ball névé densities are typical of those found in late summer névé or year-old firn (Table 1).

Angular blocks of black ice are thrown onto the ridges by wave action. Their origins are confirmed by density measurements which closely correspond to densities found in black ice several $100 \mathrm{~m}$. from the lake shore (Table 1).

\section{Other Materials}

In addition to the major constituents listed above, other materials appear in lesser quantities. Glaze often coats the ridges where wave splash has frozen on the surface. Slushy ice occasionally develops within the conglomerate mass where internal melting and refreezing has occurred. The movement and subsequent freezing of free melt water also creates thin, elongated "streams" of ice (Fig. 4, Table 1).

The sediment content of sampled ball ice and ball névé is given in Table 2. Sediment size and distribution agreed well with local Grand Marais offshore samples. It is believed that sediment load in these ridges is low compared to other Great Lakes sites. At Marquette and Charlevoix, Michigan, for example, a larger proportion of sediment content was visually apparent in the ridges. In addition size distribution is highly variable. Several sites studied in a reconnaissance during April 1971 showed a higher proportion of pebbles and gravels.

\section{MODE OF FORMATION}

The mode of formation of near-shore ice ridges is closely related to site characteristics and climatic conditions. The ridges normally develop along coast lines which have a windward exposure to open water. The north-facing shore of Lake Superior is optimal in this respect, exposed to a large body of open water with 
TABLE 2. Sediment content by weight for ball ice and ball névé, Grand Marais, Michigan

\begin{tabular}{|c|c|c|c|c|c|c|}
\hline \multirow[b]{2}{*}{$\begin{array}{c}\begin{array}{c}\text { Sediment size } \\
(\mathrm{mm} .)\end{array} \\
\end{array}$} & \multicolumn{6}{|c|}{ Percentage of sediment by weight } \\
\hline & \multicolumn{3}{|c|}{$\begin{array}{c}\text { Ball ice } \\
\text { (4 samples) }\end{array}$} & s & \multicolumn{2}{|c|}{$\begin{array}{c}\text { Ball névé } \\
\text { (2 samples) }\end{array}$} \\
\hline 4.000 & - & - & - & - & - & - \\
\hline 2.830 & - & - & - & - & - & - \\
\hline 2.000 & .58 & - & .15 & - & - & - \\
\hline 1.410 & .31 & $\overline{07}$ & .36 & $\overline{0}$ & $\bar{c}$ & $\overline{\varepsilon 1}+2$ \\
\hline 1.000 & 1.00 & .27 & .64 & 1.95 & .65 & .51 \\
\hline .707 & 3.40 & 1.92 & 2.27 & 3.62 & 2.28 & 1.01 \\
\hline .500 & 12.44 & 5.06 & 9.46 & 11.98 & 6.18 & 4.18 \\
\hline .344 & 28.00 & 15.73 & 27.21 & 27.02 & 15.29 & 19.14 \\
\hline .250 & 37.41 & 34.20 & 34.33 & 34.26 & 40.33 & 43.37 \\
\hline .177 & 14.56 & 30.10 & 20.38 & 15.32 & 29.92 & 26.23 \\
\hline .125 & 2.14 & 9.30 & 4.49 & 4.46 & 2.61 & 4.82 \\
\hline .088 & .11 & 1.64 & .55 & 1.11 & .49 & .38 \\
\hline .063 & .06 & .96 & .09 & .28 & .98 & .25 \\
\hline$<.063$ & $\operatorname{tr}$ & .82 & .06 & tr & 1.30 & $\operatorname{tr}$ \\
\hline
\end{tabular}

tr - trace

an especially long fetch. All shorelines of the Great Lakes are vulnerable, however, to ridge building processes as long as there is a period during the freeze-up with open water and an onshore flow of wind. The micro-relief of the shoreline is also critical to ridge development. Even along the north-facing Lake Superior shore, lee sides of small points, spits, and bays tend to be ridge-free or characterized by less ridge development.

The mechanism of ridge formation requires the convergence of various environmental conditions in time and place. Water temperatures must be at or closely approaching freezing, while air temperatures must be sufficiently below freezing to solidify spray droplets and wave splash before they can return to the lake. Open or partially open water is necessary just lakeward of the ridge site during a period of on-shore storm movement or heavy winds. This optimizes splash and spray processes, which provide the matrix material.

The various forms of frozen debris floating offshore determine the availability of materials to be included in the matrix. Slush, ball ice, broken chunks of beach ice, frazil, and pancake ice are among the materials that high wave action may throw onto the developing ridge. Ball ice approaching $1 \mathrm{~m}$. in diameter has been observed on the backside of $3 \mathrm{~m}$.-high ridges, a good indicator of the powerful wave processes at work. As the larger debris falls to the building-ridge surface, it is encased by the fine droplets of spray or freezing wave-wash. Thus the conglomerate-like mass builds quickly.

Structural and thermal characteristics of the ridge matrix support the above observations. Matrix crystals at or near the surface tend to be spherical or teardrop in shape, reflecting airborne freezing processes. In aggregate, they appear like tiny roe and maintain a glistening liquid veneer for several hours. Freezing and consequent cementing of the particles occurs rapidly and a classical diurnal temperature regime evolves in the ridge ice (Fig. 5). Upper profile temperatures respond rapidly to cold and variable air temperatures, whereas deeper ice reflects the insulating and dampening effects of distance from the atmosphere. At depth, 


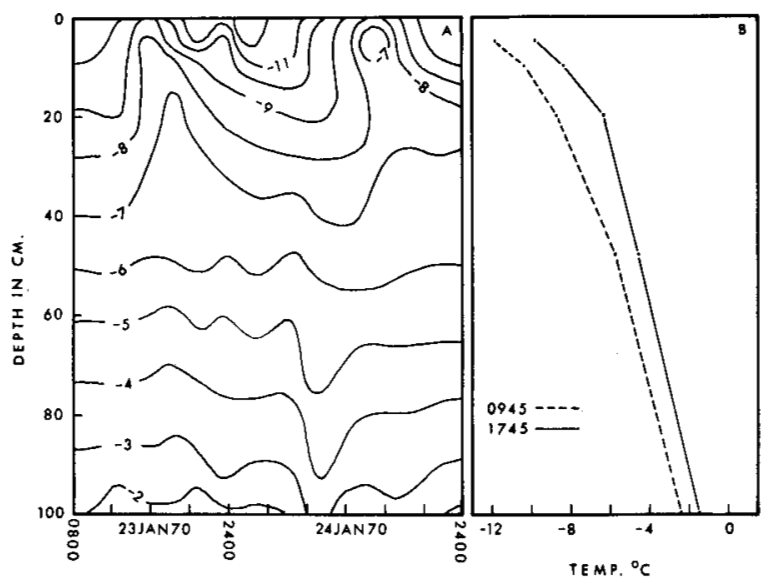

FIG. 5. A) Temperature map for ice ridge to $100 \mathrm{~cm}$., $23 \mathrm{Jan}$ uary 0800 to 24 January 2400 1970, Grand Marais, Michigan. Datum is ice ridge surface. B) Mean morning and evening temperature profiles for $22-24$ January 1970, Grand Marais, Michigan. Reference at ice ridge surface.

the matrix particles eventually metamorphose to hoar-like crystals, indicating an upward flux of vapour and localized sublimation.

The rapidity of ridge development is exemplified by the cross-sectioned illustration (Fig. 4). On Thursday 21 January, the ridge was completely trenched. Early Thursday evening, the pack ice moved slowly away from the ridge, exposing about $0.5 \mathrm{~km}$. of open water in which frazil and pancakes began to form. Around midnight the wind shifted to the north. By morning the ridge extended an additional $2 \mathrm{~m}$. in both lakeward and landward directions. The trench was almost completely filled and $1 \mathrm{~cm}$. of glaze covered much of the ridge surface. Garwood (1971) reports a similar overnight build-up near Sarnia, Ontario, in excess of 2 vertical metres. Earlier accumulation stages of the Grand Marais ridge are probably indicated by the trend of "ice streams" and sediments shown in the cross section. Later extensions of the ridge are illustrated by the profile for 22 February 1970 (inset, Fig. 4).

The rate at which ice ridges decay is partially dependent upon the fact that they are frequently grounded on sand bars. These bars may, in fact, be locators for offshore ridge formation. At the Grand Marais site, the ridges were observed to be grounded in approximately $2 \mathrm{~m}$. of water. Marsh et al. (1972), using seismic methods, confirmed that a contact exists between sand bars and ice near Grand Marais. They also state that sand bars and ice ridges are not necessarily related. Perhaps the best verification of the ice ridge-sand bar relationship was obtained during a reconnaissance flight on 18 April 1971. This was a period of ridge deterioration, and ridge remnants were clearly observed in perched position on offshore bars. The bars were continuous between the isolated ridge segments.

During the period of ridge decay, two factors are especially significant. First, south-facing exposures experience higher ablation rates. This results not only in the decrease of ridge size due to melting, but also in the decrease in albedo due to the proportional increase in sand content on south-facing ridge surfaces. A second important factor is the intrusion of water into the lagoonal area behind the outer ridge. The ice in the lagoons, which has not been grounded during the winter season, is easily disintegrated and removed, leaving the grounded ridge open to wave action on both the lakeward and shoreward sides. 


\section{CONCLUSION}

The near-shore ice ridges of the Great Lakes are primarily the result of wave and splash action and do not evolve from pressure and thrusting processes. The environmental conditions required for their formation are sub-freezing atmospheric temperature, open water at near-freezing temperatures, and shallow water. Although the mid-latitude locations of the Great Lakes argue for the development of ice ridges during the mid-winter season, it is noted that arctic and sub-arctic lakes also often possess the requisite conditions. In all locations it is a question of the frequency and magnitude at which the proper temperature and wind conditions occur. The development of a solid ice cover offshore will prevent the formation of such ice ridges.

These preliminary investigations indicate the need for further and more detailed work. Specifically the role of the ice ridges in sediment transport and coastal geomorphological processes remains unknown. Also, the modes of formation of ball ice and ball névé are incompletely understood as are the mechanisms operative in determining the spacing of ice ridges and the importance of offshore topography in this spacing.

\section{ACKNOWLEDGEMENTS}

The authors wish to express their gratitude to the Institute of Science and Technology, The University of Michigan, for a grant which made the field investigation possible. J. Dozier of The University of Michigan and W. M. Marsh of The University of Michigan at Flint provided helpful commentary on the basis of their own studies of Lake Superior shoreline features. We also wish to thank the several University of Michigan students who helped dig trenches in frequently unpleasant weather conditions.

\section{REFERENCES}

ADAMS, J, 1825. On the movement of rocks by the expansive power of freezing water. American Journal of Science, 9(23): 136-43.

ARMSTRONG, T., B. ROBERTS, and C. SWITHINBANK. 1966. Illustrated Glossary of Snow and Ice. Cambridge: Scott Polar Research Institute. $40 \mathrm{pp}$.

BUCKLEY, E. R. 1901. Ice ramparts. Transactions of the Wisconsin Academy of Science. Arts and Letters. 13: 141-62.

FAHNESTOCK, R. K., D. J. CROWLEY, M. P. WILSON, and H. I. SCHNEIDER, 1972. Lake Erie ice cones. Geological Society of America, Abstracts with Programs, 4(1): 15.

GARWOOD, C. R. 1971. An initial investigation into the reasons for the formation of shore ice structures on southern Lake Huron. Unpublished paper. Geography Department. University of Windsor. $14 \mathrm{pp}$.

GILBERT, G. K. 1885. The topographic features of lake shores. Fifth Annual Report of the United States Geological Survey to the Secretary of the Interior 1883-1884. Washington, D.C.: U.S. Government Printing Office. pp. 75-123.

GILDER, w. H. 1966. Schwatka's search: Sledging in the Arctic in quest of the Franklin records. New York: Abercrombie and Fitch. 316 pp. (Reprint of 1881 edition).

hellaAkoski, A. 1932. Jääpuristuksesta Saimaan Lietvedellä Talven 1932 Aikana. Fennia, 57(3): 3-19. (In Finnish, English summary: Ice push on Lietvesi, Lake Saimaa, during the winter of 1932. pp. 17-19.) 
HOBBS, W. H. 1911. Requisite conditions for the formation of ice ramparts. Journal of Glaciology, 19: 157-60.

JONES, J. A. A. 1970. Ice-shove: A review with particular reference to the Knob Lake area. In: Studies of lake cover in Labrador-Ungava. W. P. Adams, ed., McGill Subarctic Research Paper No. 25. pp. 223-31.

LOEWE, F. 1949. An observation of ball ice. Journal of Glaciology, 1(6): 340.

MARSH, W. M., B. D. MARSH and J. DOZIER. 1972. Structure, formation, and geomorphic influence of Lake Superior icefoots. American Journal of Science (in press).

Marshall, E. w. 1966. Air Photo Interpretation of Great Lakes Ice Features. Ann Arbor: The University of Michigan, Institute of Science and Technology, Great Lakes Division. $92 \mathrm{pp}$.

MONTAGNE, J. D. L. 1963. Ice expansion ramparts on south arm of Yellowstone Lake, Wyoming. Contributions to Geology, 2(1): 43-46.

O'HARA, N. W. and J. C. AYERS. 1972. Shore ice formation and destruction on eastern Lake Michigan. Abstracts, 15th Conference on Great Lakes Research. Madison, Wisconsin. pp. 50-51.

"PETROS". 1822. On certain rocks supposed to move without any apparent cause. American Journal of Science. 5(6): 34-37.

scot', I. D. 1927. Ice-push on lake shores. Papers, Michigan Academy of Science, Arts and Letters, 7: 107-22.

TYRrel. , J. B. 1909. Ice on Canadian lakes. Transactions of the Royal Canadian Institute, 9: $12-21$.

U. S. NAVY HYDROGRAPHIC OFFICE. 1952. A Functional Glossary of Ice Terminology. H. O. Publication No. 609. Washington, D.C.: U.S. Government Printing Office. 88 pp.

WAGNER, W. P. 1970 . Ice movement and shoreline modification, Lake Champlain, Vermont. Bulletin of the Geological Society of America. 81(1): 117-26.

WARD, W. H. 1959. Ice action of shores. Journal of Glaciology, 3(25): 437.

WOOD, J. 1825. Remarks on the moving of rocks by ice. American Journal of Science, 9(23): $144-45$.

ZUMBERge, J. H. 1952. The Lakes of Minnesota - Their Origin and Classification. Minnesota Geological Survey Bulletin 35. Minneapolis: University of Minnesota Press. 99 pp.

ZUMBERGE, J. H. and J. T. WiLson. 1953. Effect of ice on shore development. In: Proceedings of Fourth Conference on Coastal Engineering. Chicago, Ill. J. W. Johnson (ed.). Berkeley: University of California. pp. 201-05. 